\title{
The nature, extent and effect of skills shortages on skills migration in South Africa
}

\author{
Authors: \\ Fatima Rasool \\ Christoff J. Botha ${ }^{1}$ \\ Affiliations: \\ ${ }^{1}$ Potchefstroom Business \\ School, North West \\ University, South Africa \\ Correspondence to: \\ Christoff Botha \\ Email: \\ christoff.botha@nwu.ac.za \\ Postal address: \\ North West University, \\ Potchefstroom Business \\ School, Potchefstroom 2520 \\ South Africa \\ Dates: \\ Received: 13 Mar. 2010 \\ Accepted: 16 May 2011 \\ Published: 15 July 2011 \\ How to cite this article: \\ Rasool, F., \& Botha, C.J. \\ (2011). The nature, extent \\ and effect of skills shortages \\ on skills migration in \\ South Africa. SA Journal \\ of Human Resource \\ Management/SA Tydskrif vir \\ Menslikehulpbronbestuur, \\ 9(1), Art. \#287, 12 pages. \\ doi:10.4102/sajhrm.v9i1.287
}

(C) 2011. The Authors.

Licensee: AOSIS

OpenJournals. This work

is licensed under the

Creative Commons

Attribution License.
Orientation: South Africa is currently experiencing a serious shortage of skilled workers. It has a negative effect on South Africa's economic prospects and on global participation in South Africa (SA). This skills shortage severely affects socioeconomic growth and development in SA.

Research purpose: This study focuses on the causes and effects of the skills shortages in South Africa.

Motivation for the study: The researchers undertook this study to highlight the role that skilled foreign workers can play in supplementing the shortage of skilled workers in South Africa. The shortage is partly because of the failure of the national education and training system to supply the economy with much-needed skills.

Research design, approach and method: The researchers undertook a literature study to identify the nature, extent and effect of skills shortages in South Africa. They consulted a wide range of primary and secondary resources in order to acquire an in-depth understanding of the problem. The article explains the research approach and method comprehensively. It also outlines the research method the researchers used.

Main findings: This study shows that several factors cause serious skills shortages in SA.

Practical/managerial implications: The researchers mention only two significant implications. Firstly, this article provides a logical description of the nature, extent and effect of skills shortages on the economy. Secondly, it indicates clearly the implications of skills shortages for immigration policy.

Contribution/value-add: This study confirms the findings of similar studies the Centre for Development and Enterprise (CDE) conducted. Opening the doors to highly skilled immigrants can broaden the skills pool.

\section{Introduction}

The South African government is giving the issue of skills shortages considerable attention. However, skill shortages are still very real in South Africa (SA) today. The proliferation of new legislation, like employment equity legislation and the mining charter for women, reflect this. The legislation aims at developing the skills and employability of all citizens in order to alleviate poverty, address historical inequalities, create employment opportunities and improve the competitiveness of the national economy (Du Toit \& Van Tonder, 2009, pp. 20-21).

The promulgation of the Skills Development Act (No. 98 of 1999) created an enabling institutional and regulatory framework for expanding strategic investment in education and training across all economic sectors. This act led to the establishment of Sector Education and Training Authorities (SETAs), which representatives of organised labour and business manage, to promote skills development. The South African Qualifications Authority Act (No. 58 of 1995) created a national qualifications framework (NQF) to increase accessibility and portability to learners to improve their qualifications. The National Qualifications Framework Act (No. 67 of 2008) repealed this act.

Despite a number of education reforms, like changes to the school curricula, the country still faces considerable skills shortages. The media highlight this regularly and it causes criticism from social partners like employer bodies, trade unions and the government. According to Bhorat, Meyer and Mlatsheni (2002), the Centre for Development and Enterprise (2007b) and Kraak (2008), there seems to be consensus that skills shortages are major obstacles to economic growth and job creation in South Africa. 
The government's commitment to halve unemployment and poverty by 2014 led to the establishment of the Accelerated and Shared Growth Initiative for South Africa (AsgiSA).

The deputy president at the time, Ms Phumzile MlamboNgcuka, formally launched AsgiSA in February 2006. The Joint Initiative on Priority Skills Acquisition (Jipsa) was established a month later to address the scarce and critical skills SA needed to meet AsgiSA's objectives.

AsgiSA identified six 'binding constraints' that prevent South Africa from achieving its desired growth rate:

- the relative volatility of the currency

- the cost, efficiency and capacity of the national logistics system

- shortages of suitably skilled workers and the spatial distortions of apartheid that affect unskilled labour costs

- barriers to entry, limits to competition and limited new investment opportunities

- the regulatory environment and the burden on small and medium enterprises (SMEs)

- deficiencies in state organisation, capacity and leadership (see the 2011 annual reports of Jipsa and AsgiSA).

The Accelerated and Shared Growth Initiative for South Africa also stated that the 'apprenticeship system is on its way out' (2011). There have been new developments and the definition of 'learnership' includes 'apprenticeship'.

The National Treasury appointed the Harvard Group to analyse growth prospects for South Africa. It drew a similar finding on skills shortages (2008) and concluded that human resource shortages limit economic growth prospects in SA. The Human Resource Development Review (Kraak, 2008, p. 22) identified skills shortages as major impediments to socioeconomic growth and development.

Skills shortages in South Africa are the consequences of the interplay of several complex socio-political and economic factors. With the advent of democracy in 1994, the new government inherited a divided education and training system that comprised fifteen education departments the apartheid government established along racial and regional lines. The apartheid education and training system produced super-structural chaos that wasted funds, inefficiency and very poor graduate outputs aggravated (Hofmeyr \& Buckland, 1992, p. 26).

According to the Clothing, Textile, Footwear and Leather Sector Education and Training Authority (CTFL), lifting sanctions against South Africa in the 1990s, in effect, exposed the economy to international economic competition. The entry of China and India as globally competitive export economies, together with the World Trade Organisation's reduction in tariffs, placed further pressure on the domestic economy (CTFL, 2006, p. 28).

The inability of the education and training system to meet the growing demands of local firms for skilled graduates aggravates the situation. The rising aspirations of the previously disadvantaged majority of the population further compounded the demand-driven needs of the labour market (Kraak, 2008, p. 1). The South African economy experienced accelerated growth after 2002. This resulted in a shortage of skilled workers in virtually all economic sectors. See Figure 1.

Economic growth rates after 2004 increased to 5\% after averaging 3\% during the preceding 10 years. Growth increased to average $3.4 \%$ between 2000 and 2004 but increased by almost 5\% between 2004 and 2007 (South African Reserve Bank, 2011). An increase in jobs during the latter period accompanied the growth. However, the growth in employment was not high. The economy grew between 2004 and 2007 but employment tended to decline.

The recovery from the global economic meltdown in 2008 continued in the final quarter of 2010 and in the early months of 2011, its momentum stronger than many observers had expected. Major developing countries maintained high rates of economic growth. However, they were aware of the dangers of inflation and tightened their monetary policies. The recovery remained fragile in the major advanced economies. Monetary policies remained accommodative to support growth, although the major advanced economies reduced or withdrew the earlier fiscal stimuli in the interests of fiscal sustainability (South African Reserve Bank, 2011).

Apart from the shortage of skills, factors like affirmative action, emigration and employment equity also contributed to unemployment during this period. Affirmative action affected many skilled people and they thought that the government did not appreciate their talents or skills. In addition, the results of a survey the Southern Africa Migration Project conducted show that approximately $83 \%$ of White people and $20 \%$ of Black people opposed the government's affirmative action policy (McDonald \& Crush, 2002, p. 40). Emigration was the option many took.

Whilst affirmative action is one factor that contributes to the migration of skilled workers, others include crime, better wage offers, a better quality of life and future for their children, economic stability and improved health care (Bezuidenhout, Joubert, Hiemstra \& Struwig, 2009; Bornman,

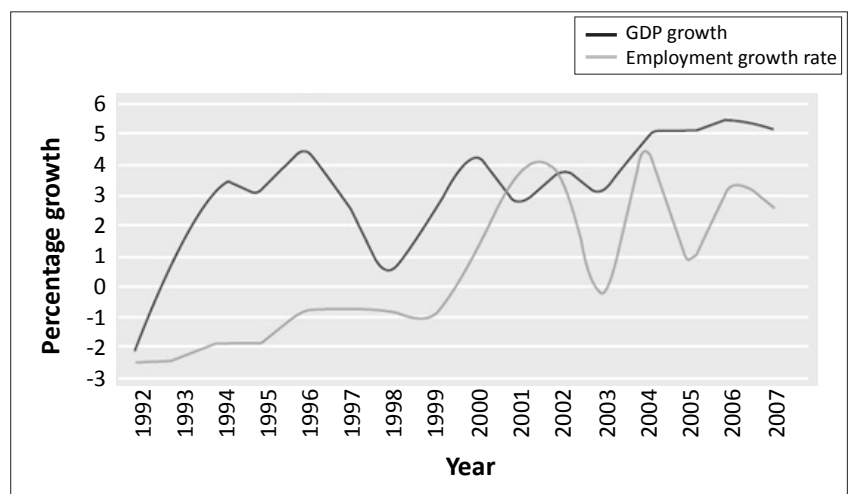

Source: South African Reserve Bank (SARB). (2008). Quarterly Bulletin, Pretoria. Retrieved March 25, 2011, from http://www.resbank.co.za/Lists/News\%20and\%20Publications/ Attachments/4066/Full\%20Quarterly\%20Bulletin.pdf

GDP, gross domestic product.

FIGURE 1: Economic growth outpaces employment growth. 
2005; Van Rooyen, 2000). Therefore, it is clear that, despite the number of efforts made to address the challenges confronting the country, skills constraints continue to affect it (McCord \& Bhorat, 2003, p. 137).

\section{Statement of the problem}

Currently there is a vigorous debate amongst various interest groups about the chronic skills shortages in the country and the inability of the education and training system to meet the demand-driven needs of the economy. Despite these debates and ongoing policy reforms, the nature of the skills shortage in South Africa remains poorly defined (CDE, 2007a, p. 11).

There is no widely accepted definition of a skills shortage or of how government should respond to it. Therefore, the nature, scale and severity of skills shortages are often miscalculated, misunderstood and misused. This results in poor public policies, with their associated high levels of wastage (Benjamin, 2008; Ellis, 2008). In addition, the reliability and validity of labour market data are worrying.

According to McCord and Bhorat (2003, p. 116), poor labour market information systems and outmoded occupational forecasting models exacerbate skills shortages. The quality of labour force data in South Africa is generally poor and those of occupational statistics are even poorer. Van Aardt (2009, p. 144) concurs that, in many situations, these statistics are available only in highly aggregated forms and contain broad categories like senior officials, managers, professionals and technicians. Admittedly, various private and public agencies conduct a considerable amount of labour market research. However, it fails to give a holistic picture of the true state of the skills shortages in SA.

One prevailing misconception is to regard the concepts of 'scarcity' of skills and 'shortage' of skills as meaning the same. The National Scarce Skills List (Department of Labour, 2006/7) refers to 'scarce' skills when, in fact, it is referring to skills 'shortages'.

There is a tendency to perceive the problem of skills shortages only from the perspective of a weak education and training system. Therefore, some argue, the only way to address skills shortages is through an increase in public investment on education and training.

Training is necessary, but it is an inadequate response to alleviating skills shortages. An increase in the public provision of training may only be appropriate if there is evidence of a decline in the ratios of persons being trained to total employment.

The Development Policy Research Unit (2007, p. 12) offers a range of other possible responses to alleviating the skills shortages. These include freeing wages, developing a progressive skills immigration policy, reviewing labour market policy and improving industrial policy, amongst others. Issues like foreign direct flows, trade penetration, technological advancements, competition policy, as well as monetary and fiscal policies also determine the skills sets the labour market demands.

From another perspective, Ellis (2008, p. 121) states that upgrading the educational system is necessary. However, this would not to produce enough entrants to the labour market to eliminate the skills shortages in the short term. Nzimande (2009) agrees that education and training by themselves cannot resolve the problem of skills shortages.

The government seems committed to addressing skills shortages. Currently, the state's contribution to public education remains the single largest investment in public services. Spending on education has grown $14 \%$ every year for the past three years and accounts for R140.4 billion in provincial and national government spending for 2008/2009 (Manuel, 2009). A promising development was the expenditure, on further education and training colleges, of over R14 billion for the period ahead and on student financial assistance, which will increase (2011 Budget Speech, 2011).

Gordhan (2011) indicated that the government has provided R9.5 billion for expanding education and training colleges and skills development further. Trevor Manuel, the minister of finance at the time, indicated in his 2009 budget speech that government had allocated close to R9 billion to public skills development programmes (Manuel, 2009). This spending could help to address the skills shortages that emigration has caused.

It includes:

- R1 billion to the Umsobomvu Youth Fund

- R1.28 billion to further education and training (FET) bursaries and recapitalisation

- R6.2 billion to sector education and training authorities

- R1.5 billion to the National Skills Fund.

For 2009, the baseline funding for FET colleges included R995 million for bursaries for 162360 students. There was also a further R285 million to recapitalise technical high schools over the next three years. The government allocated an additional R700 million for higher education subsidies to accommodate the expected growth in student numbers from 783900 in 2008 to 836800 in 2009. The government also allocated an extra R330 million to the National Student Financial Aid Scheme for poor students (Manuel, 2009). Therefore, it is clear that the government is setting aside large sums of money to improve education and training.

The figures from the 2011 Budget Speech include adjustments for remunerating teachers and an additional R24.3 billion for education and skills over the next three years. This will increase the expenditure on education and skills from R190 billion in 2011/2012 to R215 billion in 2013/14.

The government is trying desperately to increase valuable skills output through its increased education budget. However, structural changes in the economy are exacerbating 
the skills shortages. There is less emphasis on the mining, manufacturing and agriculture sectors compared to the services and financial sectors. The latter sectors generally employ highly skilled people who are in demand globally compared to mining, which employs large numbers of unskilled and semi-skilled workers (Statistics South Africa, 2008).

Table 1 gives information on occupational category movements between 1997 and 2008.

Table 1 shows considerable growth in employment for administrative and managerial, professional and technical, the service-related as well as the transport and communication occupational categories. However, there is negative growth in the clerical and sales category.

In other words, as the economy moves towards greater capital and skills intensity, the demand for unskilled workers is diminishing (McCord \& Bhorat, 2003, p. 115). This shows structural changes in the economy with a growing demand for skilled workers.

The government continues to place a high premium on development. According to Gordhan (2011), the budget proposes a range of measures to accelerate employment creation. An example is setting aside R9 billion over the next three years for a Jobs Fund to co-finance innovative publicsector and private-sector employment projects.

From a different perspective, the demand for skilled workers is acquiring a global dimension. Firms in developed countries like Australia, New Zealand, the United States of America (USA), Great Britain and Canada are recruiting highly skilled South Africans with high levels of education and advanced occupational skills (Van Rooyen, 2000, p. 62-68).

We call the loss of skilled workers the 'brain drain'. This movement also affects South Africa as thousands of skilled South Africans leave the country every year. Some of the factors that influence emigration include crime, affirmative action, Black economic empowerment, poor education standards and inadequate government provisions for health care.

A net inflow of immigrants in the 1980s has become a net outflow in the 2000s. This is a major contributing factor to the

TABLE 1: Growth in selected occupational categories during the 1997-2008 period.

\begin{tabular}{llll}
\hline Occupational category & 1997 & $\mathbf{2 0 0 8}$ & $\begin{array}{l}\text { Average growth } \\
\text { per annum (\%) }\end{array}$ \\
\hline Administrative and managerial & 370007 & 687044 & 5.79 \\
\hline Artisanal and related & 1032927 & 1083155 & 0.43 \\
Clerical and sales & 2915161 & 2437955 & -1.61 \\
Production and mining & 1728057 & 1934197 & 1.03 \\
Professional and technical & 1285313 & 1807504 & 3.15 \\
Service & 1501695 & 2279322 & 3.87 \\
\hline Transport and communication & 458053 & 779749 & 4.96 \\
\hline
\end{tabular}

Source: South African Advertising Research Foundation. (2008). All media and product survey. Johannesburg: SAARF skills crisis. The unofficial number of emigrants is estimated at three times the official number (Bhorat et al., 2002; CDE, 2008; Van Rooyen, 2000). More recently, the official number of emigrants per 1000 of the population was 4.98 (Immigration Statistics, 2011).

Attempts to recruit foreign skills to work in local firms are proving to be a challenge. From a service delivery perspective, the Department of Home Affairs is battling to process approximately 35200 quota work permit applications SA made available in 2007 to attract foreign workers to help alleviate these shortages.

In 2008, the Department of Home Affairs issued only 1010 work permits in areas of scarce and critical skills. South Africa's restrictive skills immigration policy and regulations are also very problematic (Bhorat et al., 2002; CDE, 2008; Ellis, 2008). For example, according to SA Migration International (2011), applicants with special skills or qualifications in a certain category may obtain an exceptional skills permit based solely on these skills or qualifications even if they submit no employment offer. These people must have a relevant qualification or five years of relevant experience.

\section{Objectives}

The objectives of this study are to:

- identify the nature, extent and effect of skills shortages on the economy

- determine the implications of skills shortages for immigration policy.

To achieve these objectives, the outcomes that follow are relevant:

- to determine the extent of research undertaken in the field and what remains to be learned

- to establish the nature and extent of the research problem

- to distinguish what is relevant and irrelevant to the study

- to identify different perspectives for the study

- to provide a theoretical framework for the empirical investigation

- to interpret the findings (Seaman, 1987, p. 87).

\section{Research design Research approach}

The research paradigm the researchers adopted was nonempirical (or theoretical). They conducted a comprehensive and a critical analysis of the literature on skills and skills shortages. These shortages are the consequences of the interplay between several complex socio-political and economic factors. These may include globalisation, a dysfunctional education system and structural changes in the labour market. The researchers investigated and discussed them nonempirically.

\section{Research method}

The researchers conducted a literature study to identify the nature, extent and effect of skills shortages in South Africa. 
The objectives of this study were to acquire an in-depth understanding of the problem. The researchers achieved this aim by consulting various primary and secondary sources, which they retrieved through literature searches. These sources included journals, books, periodicals, databases, government publications, international papers and others limited to the period between 1987 and 2009.

The keywords the researchers used for the literature searches included 'skills needs', 'skills shortages', 'emigration', 'brain drain', 'scarce skills' and 'immigration'. The researchers expanded the literature search using the same keywords to include 2010 and 2011 to see what authors have published.

'Emigration' yielded only three abstracts. The total number of hits the researchers obtained was 28. They included 21 abstracts. It became clear to the authors that this is a relevant topic for researchers in SA.

\section{Location of the data}

For the literature search, the researchers targeted the databases that follow during the literature phase of this study: 'Ebsco', 'Science Direct', 'Emerald', 'ISI Web of Knowledge', 'Sabinet', 'ISAP' and 'SAe pubs' that cover business, management and multidisciplinary subjects. They accessed these databases through 'EBSCOhost', an academic and business resource with a powerful search engine that provides online access to full text collections of thousands of e-journals as well as more than 100 indexing and abstracting databases. The researchers gained access to EBSCOhost through the http:/ / www.nwu. ac.za/library portal. They included South African e-journals in the search.

The researchers also reviewed the reference lists of articles for additional publications that they may not have properly indexed or found during the database searches. They also conducted Internet searches of professional organisations like http://www.bpesa.org.za and http//www.callcentres. co.za.

The researchers also included applicable data they found in electronic masters dissertations, doctoral theses and academic books from all the academic libraries in South Africa.

\section{Techniques for collecting data}

The researchers used 'emigration', 'brain drain', 'push pull', 'migration' and 'globalisation' as keywords for all the databases. The authors then focused on literature they found using Ebsco.

The researchers recorded these results from 'Ebsco':

- 'emigration': 1130 hits

- 'brain drain': 1286 hits

- 'push pull': 1041 hits

- 'migration': 27058 hits

- 'globalisation': 18404 hits.
The 'ISI Web of knowledge' yielded these results:

- 'emigration': 1186 hits

- 'brain drain': 200 hits

- 'push pull': 97 hits

- 'migration': 8088 hits

- 'globalisation': 8335 hits.

The researchers' strategy was to focus on and isolate data that suggested descriptions and/or correlations between variables that they used to formulate postulates. They considered articles that related directly to the keywords and that had links to immigration.

The researchers retrieved data from dissertations, theses and textbooks by using the search engines of the respective libraries. Where possible, they downloaded the articles in Portable Document Format (PDF), printed them and saved them in a folder.

\section{Procedures for collecting data}

The researchers then studied the data carefully and categorised them according to whether they were suited to a South African context and at least covered the extent and nature of skills or skills migration. The retained only the articles that referred specifically to the key words of this study.

The researchers noted and recorded the exact location of textbooks and articles in academic journals. In this manner, they ensured trustworthiness because the results could be replicated by using the same databases and library search engines.

\section{Analysing the data}

The researchers meta-analysed the data they gathered from the literature study. Thereafter, they extracted the literature relevant to the study and used it in their discussion. They used tables and graphs to give further information on the issues.

Finally, the researchers outlined the effects of the skills shortages.

\section{The nature and extent of skills shortages}

In order to understand the nature of skills shortages in South Africa, one has to have a working definition of the term 'skills shortage'. The literature gives several different perspectives on what a 'skills shortage' is. Studies use different definitions according to their objectives.

According to Trendle (2008, p. 9), the term 'skills shortages' applies when the quantity of skills particular work-related categories demand exceeds the supply of these skills. Shah and Burke (2003, p. 6), on the other hand, associate a skill with professional qualifications or occupations. In this 
context, one may define a skills shortage as workers that lack certain qualifications or as a shortage of workers in a particular occupation.

The Department of Education, Science and Training (2002, p. 3) acknowledges the existence of a skills shortage when an employer is unable to fill or experiences considerable difficulty in filling vacancies for an occupation at present levels of remuneration and conditions of service.

A traditional definition that appeals to economists is the one that Arrow and Capron (1959, p. 307) offer. This is that a shortage is 'a situation in which there are unfilled vacancies in positions where salaries are the same as those currently being paid to others of the same type and quality'.

\section{According to Barnow, Trutko and Robert, a skills shortage is:}

a market disequilibrium between supply and demand in which the quantity of workers demanded exceeds the supply available and willing to work at a particular wage and working conditions at a particular place and point in time.

(Barnow, Trutko \& Robert, 1998, p. 7)

This study uses this definition of a skills shortage:

A skill shortage occurs when any one of the following situations arises or a combination of them: shortage of workers in a particular occupation, labour demand exceeds availability of skills, or workers lack appropriate qualifications.

(Barnow, Trutko \& Robert, 1998; Shah \& Burke, 2003; Trendle, 2008)

This definition is appropriate for this study as it covers the situations that may cause skills shortages in this country. A few major factors that contribute to an extensive shortage of skills in South Africa are:

- globalisation

- a dysfunctional education system

- structural changes in the labour market

- a general under-investment in skills development

- emigration (Anderson, 2008; Barker, 2003; Development Policy Research Unit, 2007; Du Toit \& Van Tonder, 2009).

The issue of persisting skills shortages resurfaces in the media regularly with an ever-growing call for the government to do more to address this problem. There are frequent comments from political parties, employers and unions citing skills shortages as a major obstacle to economic growth and job creation. According to Kraak (2004, p. 70), there is a growing realisation from government that the path to national economic prosperity depends fundamentally on a highly skilled workforce.

The discussion that follows will provide an in-depth insight into the factors that contribute to these shortages.

\section{Education}

Many see the education and training system of this country as the main contributor to the national skills crisis. The system is characterised by low education standards, inadequate provision for early childhood development, declining Grade 12 pass rates, declining enrolments at FET colleges, lack of resources, under-qualified teachers, weak management and poor teacher morale. High failure rates in schools, colleges and universities offer little hope of addressing the skills shortages. According to the South African Civil Society Information Service (SACSIS), these developments are obstacles to the production skills the economy requires (SACSIS, 2009).

Despite the large sums of money the government spends on education, the outcomes are grossly inadequate. According to Pandor (2008), a 2008 survey gave a literacy rate of $36 \%$ and a numeracy rate of $35 \%$ amongst Grade 3 children. Only $10 \%$ of the children scored above $70 \%$. In addition, Grade 6 pupils who perform at Grade 3 levels and a vast majority of pupils who do not complete their schooling are very wasteful.

Benjamin (2008, p. 5) states that South Africa had come last in global studies in literacy and reading, as well as in mathematics and science. African countries like Ghana, Botswana, Morocco and Tunisia have been outperforming it. The number of South Africans completing school was also below the norm compared to other developing countries. Only $30.9 \%$ of South African adults had completed high school whilst $69.8 \%$ of adults in developed countries complete high school.

Together with the low achievement rates, only $13 \%$ of learners enrolled for science and $9 \%$ for mathematics at the higher-grade level in 2006. Figure 2 shows a decline in Grade 12 mathematics and science results between 1995 and 2001. Therefore, it reduced the supply of quality skills and the availability of required talent. The economy can only grow if there are more educated people (CDE, 2008, p. 13). The South African Civil Society Information Service (SACSIS, 2009) believes that skilled immigrants can remedy this situation temporarily.

The 1994 results were not available. The situation improved between 2001 and 2006.

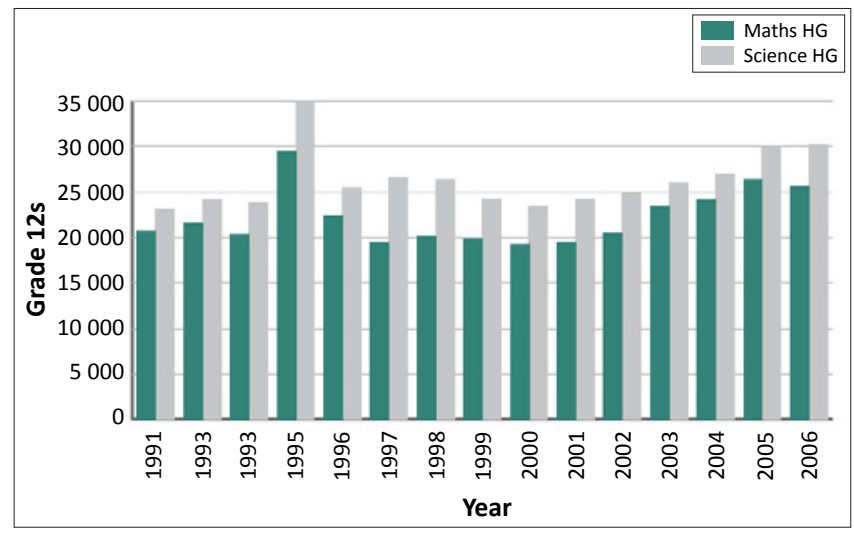

Source: Centre for Development and Enterprise. (2007a). Doubling for growth: Addressing the maths and science challenges in South Africa's schools. Pretoria: CDE $\mathrm{HG}$, higher grade.

FIGURE 2: Decline in Grade 12 mathematics and science results between 1991 and 2006 . 
Table 2 gives more information about the performance in mathematics and science in 2008.

This situation is largely the result of the poor quality of schooling for Black learners in the past. Poor results, particularly in mathematics and science, compounded the problem (see Figure 2).

Therefore, many Black students who enter tertiary institutions are reluctant to pursue careers in the science and technology fields (Pandor, 2008). Furthermore, a large number remain marginalised because they lack the specialised skills the economic turnaround requires. A university study found that nearly $50 \%$ of all dropouts aged between 18 and 20 were Black first-year students (Ray, 2009, p. 11). The March 2005 Labour Force Survey reveals that $42 \%$ of African youth between 15 and 24 years of age had stopped their studies and entered the labour market. More than $60 \%$ of them have less than a Grade 12 qualification, whilst 33\% have nothing more than Grade 12. This is a matter of great concern as the weaknesses in education are bound to affect their preparedness for the labour market and deprive them of actual employment opportunities (Kraak, 2004, p. 13).

Furthermore, estimates are that each year about 1.1 million children start Grade 1. However, only 589912 pupils sat the Grade 12 examinations in 2008. This means that half a million children drop out from school. The situation has an extensive effect on this country, especially as far as their chances of employment are concerned.

Although the government has lowered the requirements to pass, only $20 \%$ achieved a university-entrance qualification in 2008. Furthermore, only 63038 matriculates achieved 50\% in mathematics, whilst only 42323 achieved $60 \%$ and better.

Mathematics educators have questioned the standard of the mathematics examination papers. If this were to be the standard for the future, then the students would not be able to pursue mathematics-related careers like engineering, business science and architecture (Ramphele, 2009, p. 19). Making either mathematics or mathematical literacy compulsory for the National Senior Certificate (NSC) was a major step forward. It doubled the number of university entrance passes in 2008 compared to the previous year.

Almost 60000 learners passed mathematics in 2008. However, an additional 35 500, who wrote mathematical literacy, could have passed mathematics if they had written mathematics instead. This would have tripled the number of university entrance passes compared to 2007.

TABLE 2: Analysis of mathematics and science marks in 2008.

\begin{tabular}{lll}
\hline Analysis & Passes of $\mathbf{5 0 \%}$ and above & Total \\
\hline Mathematics & 58081 & 561477 \\
Science & 33734 & 561477 \\
\hline
\end{tabular}

Source: The maths and science performance of South Africa's public schools (2010). The maths and science performance of South Africa's public schools. Some lessons from the past decade. Retrieved April 18, 2011, from http://www.cde.org.za/article.php?a_id=380
Similarly, whilst almost 34000 learners passed science in 2008, approximately 27000 more learners could have passed judging by their marks in other subjects (The maths and science performance of South Africa's public schools, 2010).

If the government does not address the issues at the school level urgently and adequately, then the high dropout problems at higher education institutions will continue. According to a Human Sciences Research Council (HSRC) study, only a small percentage of students between 2002 and 2004 completed their studies in the minimum time.

Figure 3 gives the annual outflows from public higher education institutions (universities and universities of technology). The high dropout rate is costing the National Treasury R4.5 billion in grants and subsidies to universities, up from R1.3 billion in 2002. This does not augur well for alleviating the skills shortages.

According to Kraak (2004, p. 23), another shortcoming in education and training is the inefficiency of the FET sector. Students who have completed Grade 12 are expected to study courses that are on Grade 10 and Grade 11 levels.

These qualifications are actually lower than their highest level of achievement and their levels of learning are regressing. Despite this additional vocational qualification, employment opportunities are still very low. Only 33.6\% of FET graduates find employment (Kraak, 2004, p. 24). According to Akoojee et al. (2008), public further education and training in South Africa is a sector in transition. It has undergone a process of institutional transformation but still has to become more responsive to market demands and a state-led development vision.

The tertiary education system needs to link more closely to developments in industry. According to Richardson (2007, p. 17), tertiary institutions are not producing enough graduates with relevant qualifications to keep up with the demands of the labour market. They are producing graduates in fields where the demand for these skills is not growing. There appears to be a mismatch between supply from the tertiary institutions and demand from the labour market.

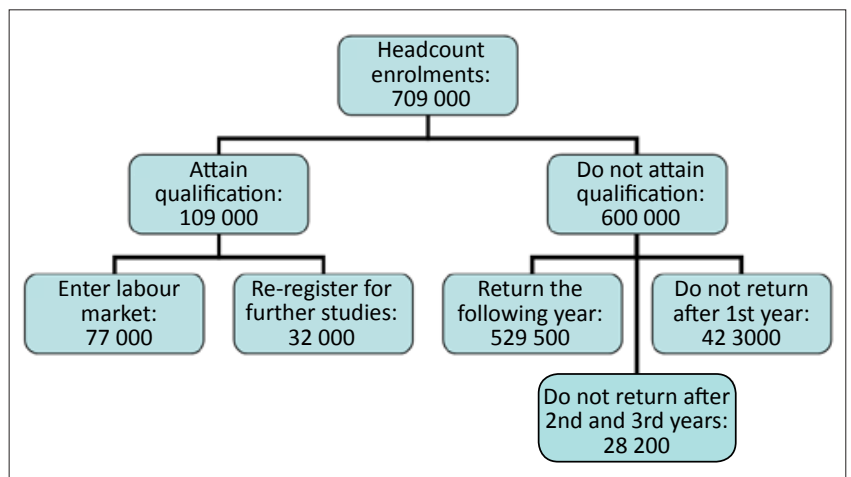

Source: Human Science Research Council. (2002-2004). HEMIS study. Pretoria: Government Printers

FIGURE 3: Annual outflows from public higher education institutions during the 2002-2004 period. 


\section{Structural changes}

The structural changes in the South African economy also contribute to skills shortages. According to Bhorat et al. (2002) and Ellis (2008), employment in some sectors has expanded whilst in others it has contracted, causing large numbers of job losses.

For example, the contributions of the mining and agricultural sectors to Gross Domestic Product (GDP) is declining compared to that of the services sector, which includes finance and business services. Factors that contributed to reducing the contribution of the mining sector include the numerous strikes by labour unions, electricity shortages and the global economic crisis. Trendle (2008, p. 3) states that the growth in the services sector, which is now worldwide, is causing a demand for skilled people, whilst there is a diminishing demand for unskilled and semi-skilled workers in mining and agriculture.

It is clear that the public sector (as well as the mining, manufacturing and construction sectors) has to use relatively more workers in order to contribute towards outputs in the economy than do the trade and financial sectors. The trade and financial sectors use only $23 \%$ of formal non-agricultural workers to contribute $44 \%$ towards total output.

This shows that sectors that use skilled people - and that are therefore less labour-intensive - contribute relatively more towards economic growth than sectors that are more labourintensive and rely on unskilled or semi-skilled workers do (the South African economy IV: Employment, 2010).

Together with structural change, new products, technology and workplace arrangements cause a change in skills needs. These skills, according to Richardson (2007, p. 9), are specific to occupations and take years to acquire. This explains the ongoing concern in South African business and policy circles about the 'skills shortage'.

However, according to Manuel (2009), issues like education and skills training, as well as what the government does about them, will determine whether the country will sustain a growth of $6 \%$ by 2010 . The country can only achieve this with an educated and efficient workforce.

\section{Emigration}

Another worrying factor in South Africa is the role of emigration in the skills crisis. According to the CDE (2010), South Africa is suffering a debilitating skills shortage. Its own skills production system is grossly inefficient and skilled people have been leaving the country at an alarming rate. This worsens the situation.

From this literature research, it is clear that South Africa needs to reform its migration policies urgently.

South Africa needs to reform other elements of its migration system as well. In particular, it needs to introduce changes to the way it implements these policies and systems.
The problem is not a new one. Official figures for 2001 indicate that South Africa lost six times more professionals and technicians than it gained. South Africa has lost approximately $20 \%$ of its skills through emigration. In addition, $70 \%$ of skilled South Africans consider emigrating (CDE, 2002, p. 5).

White skilled professionals are the majority of those who leave the country. However, there are also Black people who do. However, because of the country's history, skills are concentrated in the White population. In 1997 alone, the emigration of skilled professionals cost the government about R68 billion of investment in human capital because of the loss of skilled South Africans.

Bhorat et al. $(2002$, p. 4) believe that this huge loss of skills is very worrying. Furthermore, statistics from South African sources do not reflect this 'brain drain' accurately. However, immigration statistics from foreign countries do reflect the size of the problem (Van Rooyen, 2000, p. 26-29). The reasons for inaccurate emigration statistics include:

- emigrants not completing forms at South African airports to avoid complications if they decide to return

- the travel allowance of R500 000 does not mean they must emigrate officially

- younger skilled workers do not have large amounts of money and official emigration does not concern them (Mitchell, 2003).

There are various reasons why these skilled people emigrate. The push factors include crime, employment equity, poor working conditions, poor service delivery, high living costs, declining education standards, an unfriendly business environment, low-income levels and political events. Affirmative action is a large concern of White people (Mattes \& Richmond, 2000; Rogerson \& Rogerson, 2000). Many White South Africans have left their country because of affirmative action to seek greener pastures (Ramphele, 2008, p. 19). According to Rogerson and Rogerson (2000, p. 49), 74\% of the people who emigrated were unhappy with the level of taxation, $68 \%$ were concerned with family safety and security and $71 \%$ were unhappy with living costs.

According to Bezuidenhout et al. (2009), the migration of doctors from their home countries is not a new phenomenon. Apart from voluntary migration for various reasons, developed countries actively recruit medical professionals, often from sub-Saharan Africa. Doctors in South Africa are valued for the high standard of training they receive locally, a quality which makes them prime candidates for employment.

Various factors are involved in the push-pull theory of migration. It has, however, been reported extensively that the push factors usually play a much greater role in doctors' decision to leave their countries of origin than do pull factors in the host, or recipient, country. The push factors that motivate migration most frequently include dissatisfaction 
with remuneration packages and working conditions, high levels of crime and violence, political instability, lack of future prospects, the human immunodeficiency virus (HIV) and the acquired immunodeficiency syndrome (AIDS) as well as declining education standards. In addition to a depletion of intellectual resources through the loss of highly qualified and skilled people, countries also face substantial financial problems that the migration of doctors causes. A government subsidy of medical students' training could be a lost investment when young graduates seek permanent employment abroad.

The major pull factors are the positive factors that attract people to another country (Mattes \& Richmond, 2000, p. 32). They include attractive salary packages, early retirement in the education sector, opportunities to gain international work experience, improved lifestyles and various career choices (Du Plessis, 2009; Rogerson \& Rogerson, 2000).

\section{HIV and AIDS}

South Africa is experiencing the largest HIV and AIDS epidemic in the world. An estimated 5.6 million South Africans were HIV positive in 2008, one of the largest numbers of HIV positive people of any country in the world (Provincial HIV/AIDS Statistics, 2008). Almost one in five South Africans between the ages of 20 and 64 is HIV positive (Solomon, 2006, p. 14). Increased attrition rates because of HIV and AIDS are going to affect the country adversely in the $21^{\text {st }}$ century by diminishing the future skills pool (Mitchell, 2003). According to Maritz (2002, p. 2), people from all walks of life are affected. Loss of professionals, like engineers, doctors, managers, teachers and lawyers affects service and delivery.

Table 3 gives the effect of a no-AIDS scenario compared to an AIDS scenario on the labour force.

Whilst the HIV and AIDS epidemic is affecting people of working age mostly, the number of orphans is increasing as many of them are leaving school to take care of their younger siblings. The social grants they receive from the government partly make this possible.

\section{Crime}

According to Bheki (2009), the high crime rate is also costing South Africa much in loss of lives, revenue and

TABLE 3: Projected changes in the size of the labour force for the 2000-2015 period.

\begin{tabular}{llll}
\hline Year & $\begin{array}{l}\text { No-AIDS scenario } \\
\text { (millions) }\end{array}$ & $\begin{array}{l}\text { AIDS scenario } \\
\text { (millions) }\end{array}$ & \% difference \\
\hline 2000 & 14.5 & 14.4 & -0.7 \\
2005 & 15.8 & 15.1 & -4 \\
2010 & 17.2 & 15.1 & -12 \\
2015 & 18.7 & 14.8 & -21 \\
\hline
\end{tabular}

Source: Vass, J. (2003). The impact of HIV/AIDS, in Human Resources Development Review. Education, employment and skills in South Africa. Cape Town: HSRC skills. Therefore, it makes no sense for the Commissioner of Police, Bheki Cele, to support a moratorium on releasing crime statistics (Bheki, 2009) instead of making them public and making every attempt to enlist support to reduce crime rapidly.

He offers the reasons that follow for the moratorium:

- criminals use the statistics for their own purposes; if not released the police will be able to handle criminal incidents better

- crime statistics in certain countries are released at particular intervals and not all the time

- the statistics would be used for political mudslinging.

In addition, Maritz (2002, p. 3) states that the financial costs incurred through crime are extensive. It costs approximately R250 000 to replace a skilled worker in South Africa. Furthermore, the World Bank Investment Climate Survey for 2006 indicates that the average cost of crime for companies in the formal sector is actually $1.1 \%$ of sales, $3 \%$ of net value added, and 5\% of labour costs (World Bank, 2006). These figures negatively influence investments from large international companies. According to McDonald (2008), a study of small businesses showed that at least half of the companies had experienced a crime-related incident in the past year. Apart from business-related crime incidents, an average of 25000 people are murdered each year in the country (South African Emigration, 2003). This affects the functioning of certain sectors and decreases the skills pool. The psychological effects of crime are additional concerns. Du Preez (2002) and Du Toit and Van Tonder (2009) confirm the views of other researchers who state that crime is a major reason that skilled workers emigrate.

According to Bailey (2003, p. 249), countries with extensive skills reserves have many advantages. They handle the challenges and opportunities of globalisation easily. This is primarily because their workforce is better equipped to work with new technologies and equipment. Bailey (2003, p. 249) adds that another factor that makes these countries successful is that they are the main benefactors of skills migration as they have expansive skills immigration policies for highly skilled professionals. These countries have long understood the benefits of encouraging skilled immigration. It can serve as short-term solution and add value to the economy.

It becomes increasingly clear that South Africa has to turn to importing skills as one short-term to medium-term solution to address the inadequacies in various sectors.

\section{Findings}

The skills shortage has a widespread effect on SA. It affects the level of economic productivity and reduces the country's capacity to develop a knowledge society. This, in turn, affects the country's functioning in the global economy (Glass \& Choy, 2001; Kaplan, Meyer \& Brown, 1999). Furthermore, the loss of highly skilled workers through emigration 'would deplete the source country's level of human capital and 
thus reduce the capacity of that country to achieve as much technological progress as other economies' (Glass \& Choy, 2001, p. 9).

The article discusses a number of major effects.

\section{Effect one: The World Cup}

According to McKechnie (2008), with the Fédération Internationale de Football Association (Fifa) 2010 World Cup, the shortage of engineers, quantity surveyors, technicians and architects in the construction industry placed great pressure on infrastructural growth. There is a shortage of engineers in this country. Seven hundred engineers join the economy every year from universities. By 2010 the need was about 11000 . This means that we needed 16 times more engineers than we had (Mackenzie-Hoy, 2008).

\section{Effect two: Eskom}

According to Pickworth (2008), Eskom needs to realise that the electricity crisis is 'their problem' and that the government must intervene and introduce expensive solutions like power buy-backs or paying for generators. Eskom is set to impose a $34 \%$ hike in electricity tariffs, smaller than the $88 \%$ increase it had been considering. Eskom revised its increase because of the global economic slowdown. The inadequacies in the present education system, together with the poor results in mathematics and science, are definitely not helping. Furthermore, the apprenticeship system is underutilised. The levels of artisan training have dropped from about 300000 registered artisan apprentices in 1975 to an estimated 3000 in 2006 - a ten-fold drop.

\section{Effect three: The mining industry}

According to Macartney (2008), in an Ernst and Young report, the international mining industry is also facing critical labour shortages at all levels. Approximately a third of South Africa's engineers have left the country. According to the Engineering Council of South Africa (ECSA), approximately 300 qualified engineers leave South Africa every year (ECSA, 2007). These figures are based only on engineers who are registered with ECSA. This growing labour shortage has become a significant threat to the industry because engineers fill a large segment of senior positions in the South African mining environment. When these engineers emigrate, it is a setback to the mining sector (Swart, 2009, p.1). Problems with retaining skilled mining staff, combined with insufficient new graduates and an aging workforce, are affecting the South African industry.

According to Macartney (2008), the massive demand in the resources and construction sectors exacerbate these problems. This poses a threat to the mining industry as it also faces competition from other industries for engineers and other skilled staff. As was evident in the construction industry, apprenticeships in the mining industry have also been neglected recently. Apprenticeship programmes that Eskom and Iscor offered helped to supply skills (Macartney, 2008).

\section{Effect four: Global competitiveness}

It is clear that skills shortages are affecting the economic growth of the country and limiting its level of global participation. According to the Global Competitiveness Report (2008/2009), South Africa's world competitiveness ranking is 45th of 134 countries. Smaller countries, like Bahrain and Lithuania, are more competitive than South Africa. Consequently, South Africa is unable to secure the direct foreign investment necessary to drive the country forward economically.

\section{Effect five: Unemployment}

At present, South Africa has one of the highest unemployment rates in the world. It is largely concentrated in the young and unskilled Black population. This situation affects the economy and the stability of the whole country (Rodrik, 2006, p. 2). The high unemployment rate increases poverty and leads to higher crime levels.

\section{Discussion}

The main objectives of the study were to identify the nature, extent and effect of the skills shortages on the economy as well as to determine the implications of the skills shortages for immigration policy. The findings and results of the literature study show that the researchers achieved their objectives.

It is clear that South Africa is losing a considerable percentage of its highly skilled and skilled workers to the global economy. This situation will retard South Africa's participation in the competitive global field.

The education system is not moving quickly enough to replenish these shortages whilst HIV, AIDS and crime are issues that also need urgent solutions.

Whilst the country and the government need time to put their plans and policies on immigration and skills development in order, the country would welcome a short-term to mediumterm solution to its skills shortages.

There are several possible ways of alleviating the skills shortages. They include, amongst others:

- reviewing labour market policy as enunciated in some labour acts and codes of good practice

- improving education and training by reviewing school curricula and the role of the sector education and training authorities

- improving industrial policy

- developing a more robust skills immigration policy.

The government, business organisations and labour unions should address the immigration issue to move the country forward. President Mbeki, in his State of the Nation speech in 2001, also supported the need for skilled immigration. The Harvard Group (2008) and Boswell, Stiller and Straubhaar (2004) recommended importing highly skilled people to ease the skills shortages. 
The guiding principle should be to allow the entry of people who have the necessary skills and experience to earn a living, be tax contributors and consumers of the goods and services the country provides. Evidence suggests that skilled immigrants contribute to economic growth, create jobs and reduce the costs of worker training (CDE, 2007a, p. 46). One qualified immigrant teacher of mathematics or science can actually 'create' many jobs.

Finally, opening the doors to highly skilled immigrants could supplement the skills pool and contribute to the economic growth of the country (Van Aardt, 2009, p. 144).

\section{Limitations of the study and suggestions for future research}

A serious limitation in this study was to include research on the economic meltdown and its influence on migration patterns. South Africans, especially those in Britain, find it increasingly difficult to find jobs and job security in an economy that the global economic crisis hit hard. It seems that it is less favourable to emigrate than before the crisis.

Another limitation was the availability of trustworthy statistics for migration in general and for emigration in particular. Sources are either old or for regions other than South Africa. Therefore, the extensive literature search was necessary.

Future research on immigration and emigration, and the problems this article discussed, can focus on the large and important economies like Britain and America. Many of the 'poorer' economies are likely to lose skilled people to these countries. This can include matters like growth, unemployment and inflation.

A study on migration patterns in Southern Africa can yield answers to specific problems for this region, such as the reasons for immigration and emigration.

\section{Summary}

It is clear from the literature research that South Africa is experiencing a high shortage of skills. Factors like poor education standards, structural changes in the economy, emigration and crime are amongst the factors that contribute to this skills crisis.

Furthermore, poor labour market information systems and outmoded occupational forecasting models exacerbate the skills shortages. An example is the recent controversy about the release of labour force data for the last quarter of 2008. The data showed declining unemployment and a contracting economy.

The country needs to find solutions to overcome the skills shortages for the immediate to short term as well as the medium to long term. This will enable the country to strive towards higher economic growth and global competitiveness.

\section{Acknowledgements}

Authors' contributions

Fatima Rasool is a PhD Student enrolled at the North West University in South Africa. Her study focuses on the immigration policy of the country and she wants to contribute to job creation with this research.

Christoff Botha is an industrial sociologist and full time lecturer at the Potchefstroom Business School of the North West University in South Africa. His passion for human resources stretches over a period of more than 20 years.

\section{References}

Akoojee, S., McGrath, S., \& Visser, M. (2008). Further education and training colleges. In A. Kraak \& K. Press (Eds.), Human resources development review 2008. Education, employment and skills in South Africa, (pp. 254-277). Cape Town: HSRC Press.

Anderson, B. (17 April 2008). Dire skills gap. Finweek, p. 81.

Arrow, K.J., \& Capron, W.M. (1959). Dynamic Shortages and Price Rises: The EngineerScientist Case. Quarterly Journal of Economics, 73, 292-308. doi:10.2307/1883726

Asgisa, A. (2006). Deputy President briefing on accelerated and shared growth initiative. Retrieved February 06, 2006, from www.pmg.org.za/briefings/briefings. php?id=246

Bailey, T. (2003). Skills migration. Human Resources Development Review. Cape Town: HSRC Press.

Barker, F. (2003). The South African labour market. Pretoria: Van Schaik.

Barnow, S., Trutko, J., \& Robert, L. (1998). Skill mismatches and worker shortages: The problem and appropriate responses. Urban Institute Policy Memorandum prepared for the US Department of Labor, Washington DC

Benjamin, C. (25 November 2008). Poor education hampering SA growth effort. Business Day, p. 5.

Bezuidenhout, M.M., Joubert, G., Hiemstra, L.A., \& Struwig, M.C. (2009). Reasons for Doctor Migration from South Africa. SA Fam Pract, 51(3), 211-215.

Bheki, C. (2009). National commissioner of police, Bheki Cele seems to be wary of releasing crime statistics. Retrieved August 10, 2009, from http://www. thoughtleader.co.za/talkback

Bhorat, H., Meyer, J.B., \& Mlatsheni, C. (2002). Skilled labour migration from developing countries: Study on South and Southern Africa. International Migration developing countries: Study on South and Southern Africa. International Migration
Papers (52), International Labour Office, Geneva. Retrieved August 22, 2009, from Papers (52), International Labour Office, Geneva. Retrieved August 22, 2009, from pdf

Bornman, E. (2005). Emigrasie Onder Afrikaners Vandag [Emigration Among Afrikaners Today]. Tydskrif vir Geesteswetenskappe, 45(3), 386-399.

Boswell, C., Stiller, S., \& Straubhaar, T. (2004). Forecasting labour and skills shortages: How can projections better inform labour migration policy? Hamburg: Hamburg Institute of International Economics (HWWA).

Centre for Development and Enterprise. (2002). South Africa's new immigration law: A salvageable instrument for economic growth? Pretoria: $\mathrm{CDE}$.

Centre for Development and Enterprise. (2007a). Doubling for growth: Addressing the maths and science challenges in South Africa's schools. Pretoria: CDE.

Centre for Development and Enterprise. (2007b). The skills revolution: Are we making progress? Pretoria: CDE.

Centre for Development and Enterprise. (2008). Immigrants in Johannesburg, estimating numbers and assessing impacts. Pretoria: $\mathrm{CDE}$.

Centre for Development and Enterprise. (2010). Much of SA's maths and science potential still being wasted. Retrieved March 25, 2011, from http://www.cde.org. za/article.php?a id $=381$

Clothing, Textile, Footwear and Leather Sector Education and Training Authority (CTFL). (2006). Sector skills plan. Durban: CTFL SETA.

Department of Education, Science and Training (DEST). (2002). Nature and causes of skills shortages: Reflections from the Commonwealth National Industry Skills Initiative Working Groups. Department of Employment and Workplace Relations. Australia: Australian Government Printers.

Department of Labour. (2006/2007). State of Skills in South Africa. Pretoria: Government Press.

Development Policy Research Unit (DPRU). (2007). Skills shortages in South Africa: Key issues. DPRU Policy Brief Series. School of Economics. Cape Town: University of Cape Town.

Du Plessis, T.H. (2009). South African expatriates as potential entrepreneurs: An exploratory study. Unpublished doctoral theses. Potchefstroom: North-West University.

Du Preez, J. (2002). The Depletion of the Human Resources Pool in South Africa. Acto Commercii, 2002(2), 80-84. 
Du Toit, C., \& Van Tonder, J. (2009). South Africa's economic performance since 1994: Can we do better? In C. Parsons (Ed.), ZUMANOMICS, which way to shared prosperity in South Africa? Challenges for a new government. Retrieved March 25 2011, from http://www.clarkesbooks.co.za/assets/catalogues/catalogue120.html

Ellis, S. (2008). South Africa and international migration: The role of skilled labour In A.W. Segatti, \& L. Landau (Eds.), Migration in post-apartheid South Africa: Challenges and questions to policy makers. Retrieved March 25, 2011, frc http://mpra.ub.uni-muenchen.de/19182/

Engineering Council of South Africa (ECSA). (2007). Annual report 2006-2007. Retrieved August 14, 2009, from www.ecsa.co.za/documents/080306_2006_2007_Annual_ Report.pdf

Glass, H., \& Choy, W.K. (2001). Brain drain or brain exchange? Treasury Working Papers 01/22. Auckland: Crown.

Global Competitiveness Report. (2008/2009). Retrieved September 21, 2009, from http://www.weforum.org/GCR

Gordhan, P. (2011). South African Budget. Retrieved March 25, 2011, from http:// www.oldmutual.co.za/documents/budgetspeech/2011/BudgetHighlights.pdf

Harvard Group. (2008). Final recommendations of the international panel on growth, South Africa. Retrieved May 11, 2009, from www.treasury.gov.za

Hofmeyr, J., \& Buckland, P. (October 1992). The governance of education in South Africa. Paper presented at the meeting of NEPI planning, systems and structure research group. Cape Town: Government Printers.

Human Science Research Council. (2002-2004). HEMIS study. Pretoria: Government Printers.

Immigration Statistics. (2011). Immigration statistics: Net migration rate (most recent) by country. Retrieved March 25, 2011, from http://www.nationmaster.com/ graph/imm_net_mig_rat-immigration-net-migration-rate

Joint Initiative on Priority Skills Acquisition (Jipsa) and Accelerated Shared Growth Initiative for South Africa (AsgiSA) annual reports. (2011). Accelerated and Shared Growth Initiative for South Africa (ASGISA). Retrieved March 25, 2011, from http://www.info.gov.za/asgisa/

Kaplan, D., Meyer, J.B., \& Brown, M. (1999). Brain drain, new data: New options. Trade and industry monitor. Retrieved November 13,2009, from www.queensu. $\mathrm{ca} / \mathrm{samp} / \mathrm{migrationresources/braindrain/documents/bailey.pdf}$

Kraak, A. (2004). An overview of South African human resources development. Cape Town: HSRC.

Kraak, A. (2008). The education-economy relationship in South Africa, 2001-2005 Human Resources Development Review. Cape Town: HSRC.

Labour Force Survey. (2005). Statistics South Africa labour force survey. Retrieved July 12, 2009, from http://www.statssa.gov.za

Mackenzie-Hoy, T. (2008). Tackling shortage of engineers. Retrieved March 25 2011, from http://www.engineeringnews.co.za/article/tackling-shortage-ofengineers-2008-06-06

Macartney, A. (2008). Skills shortage in the international mining industry now at critical levels. Johannesburg: Ernst and Young.

Manuel, T. (2009). The budget speech. Retrieved March 25, 2011, from http://www. treasury.gov.za/documents/national\%20budget/2011/speech/speech2011.pdf

Maritz, G. (2002). Impacts of HIV/AIDS for business organizations: A strategic management approach. Unpublished master's theses. Johannesburg: Rand Afrikaans University.

Mattes, R., \& Richmond, W. (2000). The brain drain: What do skilled South African think? In J. Crush (Ed.), Losing our minds: Skills migration and the South African brain drain. Retrieved March 25, 2011, from http://www.sarpn.org.za/ EventPapers/april2002_imp/campbell/campbell.pdf

McCord, A., \& Bhorat, H. (2003). Overview of the South African economy. Human Resources Development Review. Cape Town: HSRC.

McDonald, A.D., \& Crush, J. (2002). Destinations unknown: Perspectives on the brain drain in Southern Africa. Pretoria: Africa Institute of South Africa.

McDonald, K. (2008). The impact of crime on small businesses in South Africa. A study commissioned by the Presidency of South Africa, July 2008, SBP, South Africa. Retrieved May 20, 2009, from http://www.sbp.org.za

McKechnie, I. (2008). Engineering shortage causes havoc. Engineering News. Retrieved August 26, 2008, from www.engineeringnews.co.za

Mitchell, J. (2003). White exodus out of South Africa. Retrieved June 10, 2009, from $\mathrm{http}: / /$ www.SouthAfricanEmigration.com/reviews.htm

News 24. (2011). Power crisis. Retrieved March 25, 2011, from http://www.news24. com/SouthAfrica/PowerCrisis

Nzimande, B. (August 2009). The post school education and training system: Some issues of policy. Paper presented at the open forum of the Minister of Higher Education and Training. Durban, South Africa.

Pandor, N. (2008). Untitled public address. Paper presented at the Foundation Phase Conference. Retrieved April 23, 2009, from http://www.search.gov.za

Pickworth, E. (2008). Power crisis Escom's problem. Retrieved March 25, 2011, from http://www.fin24.com/Economy/Power-crisis-Eskoms-problem-20080121
Provincial HIV/AIDS Statistics. (2008). South African institute of race relations: South Africa survey. Retrieved May 19, 2009, from http://www.sairr.org.za/researchAfrica survey. Retrieved May 19, 2009,
and-publications/the-south-africa-survey

Ramphele, M. (31 August 2008). Job equity needs a lot of work. Sunday Times, p. 19. Ramphele, M. (18 January 2009). Another generation betrayed. Sunday Times, p. 19. Ray, M. (11 June 2009). Blade Runner. Finweek, p. 11.

Republic of South Africa. (1995). The South African Qualifications Authority Act No.58 of 1995. Pretoria: Government Printer.

Republic of South Africa. (1998). Skills Development Act No. 98 of 1999. Pretoria: Government Printer.

Richardson, S. (2007). What is a Skill Shortage? National Institute of Labour Studies. Adelaide: Flinders University.

Rodrik, D. (August 2006). Understanding South Africa's economic puzzles. Working paper 130. Centre for International Development. Boston: Harvard University.

Rogerson, C.M., \& Rogerson, J.M. (2000). Dealing in scarce skills: Employer responses to the brain drain. In J. Crush (Ed.), Losing our minds: Skills migration and the South African brain drain. Retrieved March 25, 2011, from http://www. thefreelibrary.com/iders\%3A+nationalism,+globalization+and+the+South+Africa thefreelibrary.com/

Seaman, C.H. (1987). Research methods: Principles, practices and theory of nursing. New York: Appleton and Lange.

Shah, C., \& Burke, G. (November 2003). Skill shortages: Concept measurement and Implications. Working paper 52. Department of Employment and Workplace Relations (DEWR). Melbourne: Centre for the Economics of Education and Training.

Solomon, H. (2006). Why Cosatu has got it wrong. CIPS electronic briefing paper 41 Centre for International Political Studies. Pretoria: University of Pretoria.

South African Advertising Research Foundation. (2008). All media and product survey Johannesburg: SAARF.

South African Emigration. (2003). General statistics on South African emigration. Retrieved May 04, 2009, from http://www.SouthAfricanEmigration.com/did-youknow.htm

South African Emigration. (2003). General statistics on South African emigration - Why people leave SA. Retrieved May 04, 2009, from http://www. SouthAfricanEmigration.com/why-emigrate.htm

South Africa Migration International. (2011). Visas and permits for South Africa. Retrieved March 25, 2011, from http://www.sami.co.za/quota.htm

South African Reserve Bank (SARB). (2008). Quarterly Bulletin, Pretoria. Retrieved March 25, 2011, from http://www.resbank.co.za/Lists/News\%20and\%20 Publications/Attachments/4066/Full\%20Quarterly\%20Bulletin.pdf

South African Reserve Bank (SARB). (2011). Quarterly Bulletin, Pretoria. Retrieved March 25, 2011, from www.resbank.co.za

Statistics South Africa. (June 2008). Quarterly employment statistics. Pretoria: Statistics South Africa.

Swart, J.H. (2009). Potential emigration of engineers in a large mining organisation An exploratory study. Unpublished master's theses. Potchefstroom: North-West University.

The maths and science performance of South Africa's public schools. (2010). The maths and science performance of South Africa's public schools. Some lessons from the past decade. Retrieved April 18, 2011, from http://www.cde.org.za/ from the past decad
article.php?a_id=380

The South African Civil Society Information Service (SACSIS). (2009). Immigration's contributions to South Africa's development: Is it a good thing? Retrieved October 12,2009 , from www.sacsis.org.za

The South African economy IV: Employment. (2010). Your online encyclopedia Retrieved March 25, 2011, from http://myfundi.co.za/e/The_South_African_ economy_IV:_Employment

Trendle, B. (2008). Skill and labour shortages - definition, cause and implications. Working Paper 54. Labour Market Research Unit. Queensland: Queensland Government Press.

Van Aardt, C. (2009). Labour policy and job creation: Too many holy cows? In C. Parsons (Ed.), ZUMANOMICS. Which way to shared prosperity in South Africa? Challenges for a new government. Retrieved March 25, 2011, from https:// my.unisa.ac.za/portal/tool/2cdf766e-b24b-4879-8032-d3ea5dbefe3a/contents/ faculties/ems/docs/CFVI_report.pdf

Van Rooyen, J. (2000). The new great trek: The story of South Africa's white exodus. Pretoria: Unisa Press

Vass, J. (2003). The impact of HIV/AIDS, in Human Resources Development Review. Education, employment and skills in South Africa. Cape Town: HSRC.

World Bank. (2006). An assessment of the investment climate. Report 34907. Retrieved March 09, 2009, from http://go.worldbank.org

2011 Budget Speech. (2011). The budget speech. Retrieved March 25, 2011, from http://www.treasury.gov.za/documents/national\%20budget/2011/speech/ speech2011.pdf 